\title{
Ocean acidification shows negligible impacts on high-latitude bacterial community structure in coastal pelagic mesocosms
}

\author{
A.-S. Roy $^{1}$, S. M. Gibbons ${ }^{2,3}$, H. Schunck ${ }^{1}$, S. Owens ${ }^{2,8}$, J. G. Caporaso ${ }^{2,4}$, M. Sperling ${ }^{1,9}$, J. I. Nissimov $^{5}$, S. Romac $^{6}$, \\ L. Bittner ${ }^{6}$, M. Mühling ${ }^{10}$, U. Riebesell ${ }^{1}$, J. LaRoche ${ }^{1, *}$, and J. A. Gilbert ${ }^{2,7}$ \\ ${ }^{1}$ GEOMAR Helmholtz Center for Ocean Research Kiel, Düsternbrooker Weg 20, 24105, Kiel, Germany \\ ${ }^{2}$ Argonne National Laboratory, Institute for Genomic and Systems Biology, 9700, S. Cass Ave. Lemont, IL 60439, USA \\ ${ }^{3}$ Graduate Program in Biophysical Sciences, University of Chicago, Chicago, IL 60637, USA \\ ${ }^{4}$ Department of Computer Science, Northern Arizona University, Flagstaff, AZ 86001, USA \\ ${ }^{5}$ Plymouth Marine Laboratory, Prospect Place, Plymouth, Devon, PL1 3DH, UK \\ ${ }^{6}$ CNRS, UMR7144 (Paris 6), Université Pierre et Marie Curie, Station Biologique de Roscoff, Place Georges Teissier, 29682 , \\ Roscoff, France \\ ${ }^{7}$ Department of Ecology and Evolution, University of Chicago, 5801 South Ellis Avenue, Chicago, IL 60637, USA \\ ${ }^{8}$ Computation Institute, University of Chicago, 5640 South Ellis Avenue, Chicago, IL 60637, USA \\ ${ }^{9}$ Alfred-Wegener-Institute, Am Handelshafen 12, 27570, Bremerhaven, Germany \\ ${ }^{10}$ Institute of Biological Sciences, TU Bergakademie Freiberg, Leipziger Str. 29, 09599, Freiberg, Germany \\ * present address: Dalhousie University, 5850 University Avenue, Halifax, NS, B3K 6R8, Canada
}

Correspondence to: A.-S. Roy (sroy@geomar.de)

Received: 31 August 2012 - Published in Biogeosciences Discuss.: 26 September 2012 Revised: 19 December 2012 - Accepted: 2 January 2013 - Published: 29 January 2013

\begin{abstract}
The impact of ocean acidification and carbonation on microbial community structure was assessed during a large-scale in situ costal pelagic mesocosm study, included as part of the EPOCA 2010 Arctic campaign. The mesocosm experiment included ambient conditions (fjord) and nine mesocosms with $p \mathrm{CO}_{2}$ levels ranging from $\sim 145$ to $\sim 1420 \mu \mathrm{atm}$. Samples for the present study were collected at ten time points $(t-1, t 1, t 5, t 7, t 12, t 14, t 18, t 22, t 26$ to $t 28$ ) in seven treatments (ambient fjord $(\sim 145), 2 \times \sim 185$, $\sim 270, \sim 685, \sim 820, \sim 1050 \mu \mathrm{atm})$ and were analysed for "small" and "large" size fraction microbial community composition using 16S rRNA (ribosomal ribonucleic acid) amplicon sequencing. This high-throughput sequencing analysis produced $\sim 2000000016 \mathrm{~S}$ rRNA V4 reads, which comprised 7000 OTUs. The main variables structuring these communities were sample origins (fjord or mesocosms) and the community size fraction (small or large size fraction). The community was significantly different between the unenclosed fjord water and enclosed mesocosms (both control and elevated $\mathrm{CO}_{2}$ treatments) after nutrients were added to the mesocosms, suggesting that the addition of nutrients is the
\end{abstract}

primary driver of the change in mesocosm community structure. The relative importance of each structuring variable depended greatly on the time at which the community was sampled in relation to the phytoplankton bloom. The sampling strategy of separating the small and large size fraction was the second most important factor for community structure. When the small and large size fraction bacteria were analysed separately at different time points, the only taxon $p \mathrm{CO}_{2}$ was found to significantly affect were the Gammaproteobacteria after nutrient addition. Finally, $p \mathrm{CO}_{2}$ treatment was found to be significantly correlated (non-linear) with 15 rare taxa, most of which increased in abundance with higher $\mathrm{CO}_{2}$.

\section{Introduction}

The acidification of our oceans, caused predominantly by dissolution of anthropogenic carbon dioxide $\left(\mathrm{CO}_{2}\right)$ in seawater, has the potential to affect the physiology of marine microbes. Therefore, because marine microbes play a major role in global biogeochemical cycles, this increase may 
have unforeseen consequences on ocean biogeochemistry (Falkowski et al., 2008; Worden and Not, 2008). Experimental manipulation of the partial pressure of carbon dioxide $\left(p \mathrm{CO}_{2}\right)$ in marine mesocosms has demonstrated speciesspecific physiological responses to elevated dissolved $\mathrm{CO}_{2}$ concentrations. For example, delayed or decreased coccolithophore calcification (Delille et al., 2005), a significant increase in photosynthetic capacity (Fu et al., 2008), higher $\mathrm{CO}_{2}$ and $\mathrm{N}_{2}$ fixation (Hutchins et al., 2007), and a decreased abundance of picoeukaryotes (Newbold et al., 2012) have been observed. However, the response of bacterial communities to elevated $p \mathrm{CO}_{2}$ concentrations is less defined, with mixed reports of both significant increases in bacterial protein production (Grossart et al., 2006), and no significant changes in microbial community structure (Tanaka et al., 2008; Allgaier et al., 2008; Newbold et al., 2012). For example, during the 2008 PeECE III mesocosms study, elevated $p \mathrm{CO}_{2}$ had no significant impact on bacterial abundance, diversity, or activity; however, the community structure of the small size fraction bacteria was significantly altered by the induced phytoplankton bloom (Allgaier et al., 2008; Arnosti et al., 2011; Riebesell et al., 2008).

While these existing studies have observed little impact of elevated $p \mathrm{CO}_{2}$ on microbial community structure, they were all performed with molecular techniques that offered limited taxonomic resolution (e.g. High-Performance Liquid Chromatography, Denaturing Gradient Gel Electrophoresis, Terminal Restriction Fragment Length Polymorphism). To improve that resolution, this study employed high-throughput amplicon sequencing of $16 \mathrm{~S}$ rRNA to characterize microbial taxonomic community dynamics. High-throughput amplicon sequencing provides an efficient method to obtain a deep molecular overview of microbial community structure, without having to cultivate environmental isolates (Agogué et al., 2011; Gilbert et al., 2009; Hubert et al., 2007; Huse et al., 2008; Margulies et al., 2005; Sogin et al., 2006). In this study, the variation of microbial assemblages was characterised through time, across a gradient of $p \mathrm{CO}_{2}$, in a largescale in situ pelagic mesocosm experiment in the coastal Arctic Ocean. In addition to characterizing the detailed response of the microbial community structure to elevated $p \mathrm{CO}_{2}$, the analysis of the 16S rRNA database provided insight on the effect of isolating the water column in a mesocosm, and to investigate the community structure response to elevated $p \mathrm{CO}_{2}$.

\section{Methods}

\subsection{Location and carbonate system manipulation}

The European Project on Ocean Acidification (EPOCA) supported a large mesocosm experiment in the Arctic which was conducted in the water of Kongsfjorden, Svalbard, Norway $\left(78^{\circ} 56.2^{\prime} \mathrm{N}, 11^{\circ} 53.6^{\prime} \mathrm{E}\right)$ during the months of June and July
2010. Throughout the experiment, diverse environmental parameters were measured to explore the effect of ocean acidification (OA) on multiple biological processes. Briefly, nine mesocosms containing about $45 \mathrm{~m}^{3}$ of seawater and reaching down to $15 \mathrm{~m}$ depth were deployed from $\mathrm{Ny}$-Ålesund and $p \mathrm{CO}_{2}$ was manipulated by the addition of $\mathrm{CO}_{2}$-saturated seawater in seven mesocosms, resulting in initial $p \mathrm{CO}_{2}$ ranging from $\sim 286$ to $\sim 1420 \mu \mathrm{atm}$. Two of the mesocosms were not manipulated and served as controls with starting $p \mathrm{CO}_{2}$ of $\sim 185 \mu \mathrm{atm}$. Additionally, samples were taken directly from the fjord (initial $p \mathrm{CO}_{2} \sim 145 \mu \mathrm{atm}$ ) in which the mesocosms were suspended and from which the mesocosm water originated. These samples were used to monitor any natural changes in $p \mathrm{CO}_{2}$ that may occur in the ambient water during the course of the experiment and were also important for detecting deviations in $p \mathrm{CO}_{2}$ between the fjord and the untreated mesocosms with time. To promote phytoplankton growth, all nine mesocosms were subjected to nutrient additions (nitrate $\left(\mathrm{NO}_{3}\right)$, phosphate $\left(\mathrm{PO}_{4}\right)$ and silicate $(\mathrm{Si}))$ on day $(t) 13$, creating pre-nutrient ( $t-1$ to $t 12)$ and post-nutrient ( $t 13$ to $t 30$ ) periods (Fig. 1). Detailed information about the experimental set-up, the mesocosms deployment, the carbonate chemistry, and the nutrients additions can be found in this issue in Riebesell et al. (2013), Czerny et al. (2013a, b), Bellerby et al. (2013), and Schulz et al. (2013), respectively.

\subsection{Sampling, filtration and sample selection}

A total of $10 \mathrm{~L}$ of water was collected using integrated water sampler (Hydrobios, Kiel, Germany) between 0 and $12 \mathrm{~m}$ water depth, from the fjord $(\sim 145 \mu \mathrm{atm})$, and six mesocosms (starting $p \mathrm{CO}_{2}=2 \times \sim 185, \sim 270, \sim 685, \sim 820$, $\sim 1050 \mu \mathrm{atm})$ on $t-1, t 1, t 5, t 7, t 12, t 14, t 18, t 22, t 26$ and $t 28$ (Fig. 1). Only six of the mesocosms were chosen for this study due to time, personnel and equipment constraints. The collected water was first pre-filtered on a $20 \mu \mathrm{m}$ sieve, and sequentially filtered through a $10 \mu \mathrm{m}$, a $3 \mu \mathrm{m}$ filter to isolate associate-particle bacterial fraction (large size fraction) and through a $0.2 \mu \mathrm{m}$ filter to isolate the small size fraction (Durapore ${ }^{\circledR} 47 \mathrm{~mm}$, Millipore). To avoid nucleic acid degradation, processing of the samples from filtration to flashfreezing (in liquid nitrogen) was performed within $30 \mathrm{~min}$ of the sampling event. Samples were then stored at $-80^{\circ} \mathrm{C}$ until DNA/RNA extraction.

\subsection{DNA extraction, PCR, and Sequencing}

Total nucleic acid was extracted from the 0.2 and $3 \mu \mathrm{m}$ filters using the "Total RNA and DNA purification - NucleoSpin ${ }^{\circledR}$ RNA II RNA/DNA buffer" kits from Macherey-Nagel (Macherey-Nagel GmbH \& Co. KG, Düren, Germany). Standard protocol with minor modifications was followed. Changes to the protocol included making the filters brittle by immersing the samples in liquid nitrogen while still 


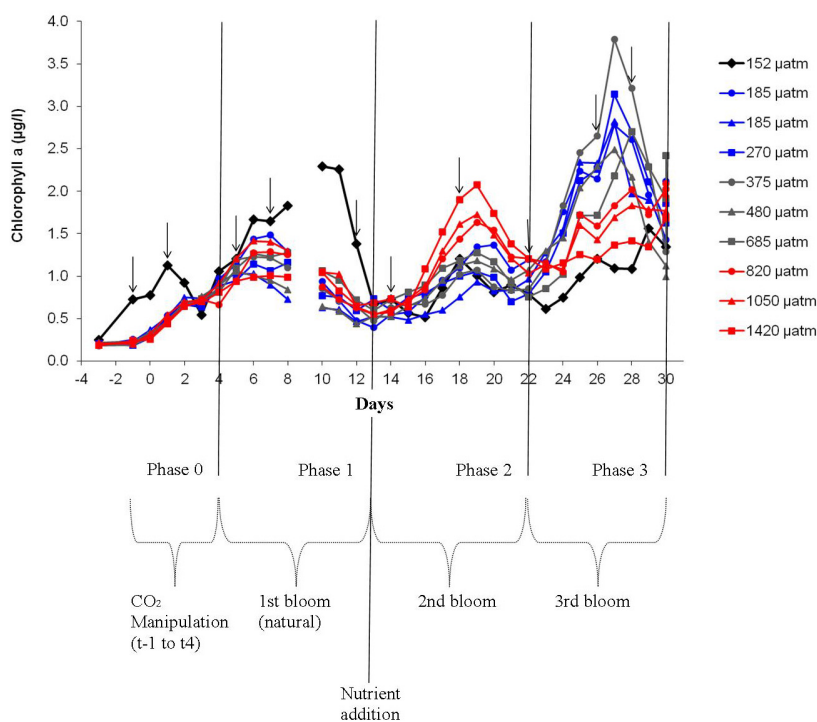

Fig. 1. Chlorophyll $a\left(\mu \mathrm{g} \mathrm{L}^{-1}\right)$ concentration measurements plotted against days, where arrows mark time points analysed in the present study. Figure derived from Schulz et al. (2013).

in the cryovials to facilitate disruption and homogenization. The filters were crushed with RNase-free plastic pestles and lysozyme was directly added to the broken filter pieces while still in the cryovial. Both the RNA and DNA were isolated during the experiment. However, the RNA was kept for further purposes. DNA quality and quantity were assessed by micro-volume spectrophotometer nanodrop ND-1000 (PeqLab GmbH, Erlangen, Germany) measurements. All samples were kept at $-80^{\circ} \mathrm{C}$ until further analysis.

Polymerase chain reaction (PCR) and sequencing were performed following the Illumina HiSeq2000 and MiSeq V416S rRNA protocol (Caporaso et al., 2012). Briefly, the V4 region of the $16 \mathrm{~S}$ rRNA gene was amplified with regionspecific primers that included the Illumina paired-end flowcell adapter sequences (Illumina Inc., CA, USA). The barcode was read using the custom index sequencing primer in an additional cycle (12 bp). Each sample was amplified in triplicate, and was pooled afterwards. Each $25 \mu \mathrm{L}$ PCR reaction contained $12 \mu \mathrm{L}$ of MoBio PCR Water (certified DNA-free), $10 \mu \mathrm{L}$ of 5 Prime HotMasterMix, $1 \mu \mathrm{L}$ of Forward Primer ( $5 \mu \mathrm{M}$ initial concentration), $1 \mu \mathrm{L}$ Golay Barcode Tagged Reverse Primer ( $5 \mu \mathrm{M}$ initial concentration), and $1 \mu \mathrm{L}$ of template DNA. The reactions were heated to $94^{\circ} \mathrm{C}$ for $3 \mathrm{~min}$ for their initial denaturation, followed by 35 cycles in series of $94^{\circ} \mathrm{C}$ for $45 \mathrm{~s}, 50^{\circ} \mathrm{C}$ for $60 \mathrm{~s}$, and $72^{\circ} \mathrm{C}$ for $90 \mathrm{~s}$. The amplicons were quantified using Quant-it ${ }^{\mathrm{TM}}$ Picogreen ${ }^{\circledR}$ (Invitrogen by Life Technologies ${ }^{\text {TM }}$, CA, USA), and pooled in equal amounts (ng) into a $1.5 \mathrm{~mL}$ tube. Once pooled, the entire amplicon pool was cleaned up with the MO-BIO UltraClean ${ }^{\circledR}$ PCR Clean-Up Kit (MO-BIO Laboratories, Inc., CA, USA). Finally, the pooled samples were quantified using a Qubit ${ }^{\circledR}$ fluorometer (Invitrogen by Life Technologies ${ }^{\mathrm{TM}}$, CA, USA), and the molarity was estimated based on amplicon length. From this estimate, dilutions were made down to $2 \mu \mathrm{M}$ and the standard Illumina sample preparation for sequencing was followed. Pooled amplicons were sequenced using custom sequencing primers, Read 1, Read 2 , and Index. These sequencing primers were designed to be complementary to the $\mathrm{V} 4$ amplification primers to avoid sequencing of the primers. Amplicons were sequenced in a paired-end, $100 \mathrm{bp} \times 100 \mathrm{bp}$ cycle run on the Illumina HiSeq2000, at a concentration of $4 \mathrm{pM}$ with a $10 \% \mathrm{PhiX}$ spike. An entire control lane devoted to PhiX is also useful when sequencing low base diversity samples, like amplicons, and was included in the present analysis.

\subsection{Sequence data analysis}

All sequence analyses were performed using Quantitative Insights Into Microbial Ecology v. 1.5.0 (QIIME; Caporaso et al., 2010). QIIME defaults were used for quality filtering of raw Illumina data (including chimeras). Unique operational taxonomic units (OTUs) were picked against the Greengenes (McDonald et al., 2012) database and pre-clustered at $97 \%$ identity; sequences that did not hit the reference collection were discarded. Representative sequences were aligned to the Greengenes core set with PyNAST (Caporaso et al., 2010). All sequences that failed to align were discarded. A phylogenetic tree was built from the alignment, and taxonomy was assigned to each sequence using the Ribosomal Database Project (RDP) classifier (Wang et al., 2007) retrained on Greengenes. Samples were rarefied to an even depth of 81181 sequences and only the OTUs that appeared at least twice in the dataset were included in the further analyses; 106 singleton OTUs were not included in this analysis.

\subsection{Statistical analysis}

Multivariate analysis of microbial community structure was carried out in CANOCO 4.54 (ter Braak and Šmilauer, 2002), where the count of each OTU ( $97 \%$ similarity) was used as a measure of abundance. All analyses had samples as scaling focus, and all species data were Hellinger-transformed using the program PrCoord 1.0 (Legendre and Gallagher, 2001; ter Braak and Šmilauer, 2002). Analysis of variance (ANOVA) followed by a Tukey test was done to test for significant differences between treatments (i.e. control vs. fjord, fjord vs. mesocosm, control vs. mesocosm) within each abundant phylum. Detrended correspondence analysis of the transformed OTU abundance data showed axis lengths $<3.0$, suggesting a linear treatment of the data (Ramette, 2007). Redundancy analysis (RDA), with manual forward selection and Monte Carlo permutation tests (999 permutations), was used to evaluate effects of environmental variables (salinity, temperature, $\mathrm{pH}$, chlorophyll $a$, etc.) on the microbial community composition. An indirect gradient analysis ( $\mathrm{PCoA})$ 
was used to plot the distribution of samples in ordination space, with important environmental variables (as indicated by forward selection) overlaid as supplementary data. Microbial community composition differences were assessed by UniFrac (Lozupone and Knight, 2005) distance using QIIME (Caporaso et al., 2010).

In order to assess whether or not particular taxa were significantly influenced by $p \mathrm{CO}_{2}$, a Bonferroni-corrected g-test was done using QIIME to remove significance due to chance. All analyses were considered to have a significant difference if $p<0.05$ after Bonferroni correction.

Contour plots presenting mean abundance count plotted against $p \mathrm{CO}_{2}$ and time (days) of the three most abundant genus of the OTUs significantly correlated to $p \mathrm{CO}_{2}$ were created using Ocean data view (Bremen, Germany).

\section{Results}

The 256 sequenced samples generated $\sim 20000000$ 16S rRNA V4 reads ( $\sim 2510000$ sequences per treatment); which clustered at $97 \%$ sequence identity into 6821 OTUs.

\subsection{Experimental timeline}

Phytoplanktonic bloom evolution was identified using the daily measured chlorophyll $a(\mathrm{chl} a)$ concentration $\left(\mu \mathrm{g} \mathrm{L}^{-1}\right)$ (Fig. 1). The chl $a$ protocol and patterns are presented in Schulz et al. (2013). Briefly, all treatments (fjord included) underwent a natural bloom between $t 0$ and $t 11$, with highest chl $a$ concentrations on $t 6$. Subsequently, a second and third strong phytoplankton bloom happened only in the mesocosms following nutrient addition on $t 13$. The second bloom had its highest chl $a$ concentration on $t 19$ and the third one, which varied greatly between mesocosms, reached its highest concentration on $t 27$. These 3 blooms were represented as four general phases in phytoplankton chlorophyll phases defined by Schulz et al. (2013): phase 0 occurred from the start of the experiment on $t-4$ until adjustment of $\mathrm{CO}_{2}$ was completed on $t 4$; phase 1 started with the end of $\mathrm{CO}_{2}$ addition on $t 4$ until the nutrient additions on $t 13$; phase 2 included the end of the first bloom on $t 13$ to the end of the second bloom on $t 22$; and phase 3 started from the end of the second bloom on $t 22$ and lasted until the end of the experiment, on $t 30$ (the chl $a$ minimum of the third bloom was not recorded) (Fig. 1). Detailed fluctuations of chl $a$, nutrient concentrations, $\mathrm{pH}$ and $p \mathrm{CO}_{2}$ are presented in this issue in Schulz et al. (2013) and Bellerby et al. (2013).

\subsection{Community-structuring variables}

The significant structuring variables for the total community during the post-nutrient addition period $(t 13-t 30)$ of the experiment were (in order of explanatory importance) "fjord vs. mesocosm origin" (i.e. whether the sample was from water contained in a mesocosm or from the open fjord), sampling strategy (i.e. physical fractionation into small and large particle sizes), $\mathrm{Si}$ concentration, $\mathrm{PO}_{4}$ concentration, mean primary production $14 \mathrm{C}-\mathrm{POC}(\mathrm{PP})$, temperature $(T)$, and $\mathrm{pH}$ (Fig. S1 and Table 1). The microbial community in the small size fraction $(0.2-3 \mu \mathrm{m})$ from the fjord and all the analysed mesocosms was dominated by Proteobacteria (in order of abundance: Gamma $(\gamma)$ - , Alpha $(\alpha)$ - and Beta $(\beta)$ - proteobacteria) throughout the experiment. However, Proteobacteria began dropping in abundance gradually after $t 7$, coincidentally with the increase in the abundance of Bacteroidetes (Fig. 2). In the large size fraction (3-12 $\mu \mathrm{m})$ Bacteroidetes dominated consistently, while a fourth group comprised of the "Cyanobacteria and eukaryotic chloroplasts" (which included Chlorophyta, Haptophyceae, Rhodophyta and Stramenopiles) were also abundant (Fig. 2). The group classified as "others" in the small size fraction was composed predominately of Cyanobacteria at the beginning of the experiment, and of Actinobacteria towards the end (Fig. S2). In the large size fraction, the "others" group was extremely variable until $t 7$. For example, at $t-1$ the fjord "others" group was dominated by the Verrucomicrobia while the mesocosms "others" groups was dominated by Actinobacteria; by $t 5$ Firmicutes dominated in most mesocosms, while being almost absent from the fjord. At $t 7$, the Actinobacteria was the dominant taxa in the "others" group in all treatments for the remainder of the experiment. At the end ( $t 28)$, some Verrucomicrobia increased in the control, $\sim 270$, and $\sim 685 \mu$ atm mesocosms (Fig. S2).

Once the community was analysed with regard to filter size fraction (small vs. large size fraction), the structuring community variables varied. The fjord had a significantly different assemblage from the mesocosms in the small and large size fraction before (origin $3 \%-4 \%$ ) and after (origin $48 \%-12 \%$ ) mesocosm nutrient addition (Table 2); however, the fjord and mesocosm communities were not significantly different until after $t 5$. The microbial community in the fjord small size fraction was not significantly different from the mesocosms communities in the pre-nutrient addition phase and only the $\gamma$-proteobacterial abundance was significantly different $(p<0.05)$ between fjord and mesocosm in the post-nutrient addition phase. The fjord large size fraction microbial community was significantly different from the mesocosms during both the pre- and post-nutrient addition phases. In particular, the "Cyanobacteria and eukaryotic chloroplasts" group was significantly different between fjord and mesocosms pre- and post-nutrient addition; while the Bacteroidetes, $\alpha$-proteobacteria and "others" were only significantly different post-nutrient addition (Fig. 3 and Table 3). Furthermore, the significant variables that correlated with community structure changes in the small size fraction were dimethyl sulphide (DMS-16\%), bacterial production (bp-15\%), density (d-12\%) for the pre-nutrient period $(t-4$ to $t 12)$, and origin $(48 \%), p \mathrm{CO}_{2}(10 \%)$, day $(10 \%)$ for the post-nutrient period $(t 13-t 30$; Table 2$)$. For the large size fraction, these variables were oxygen $\left(\mathrm{O}_{2}-7 \%\right)$, DMS $(7 \%)$, 


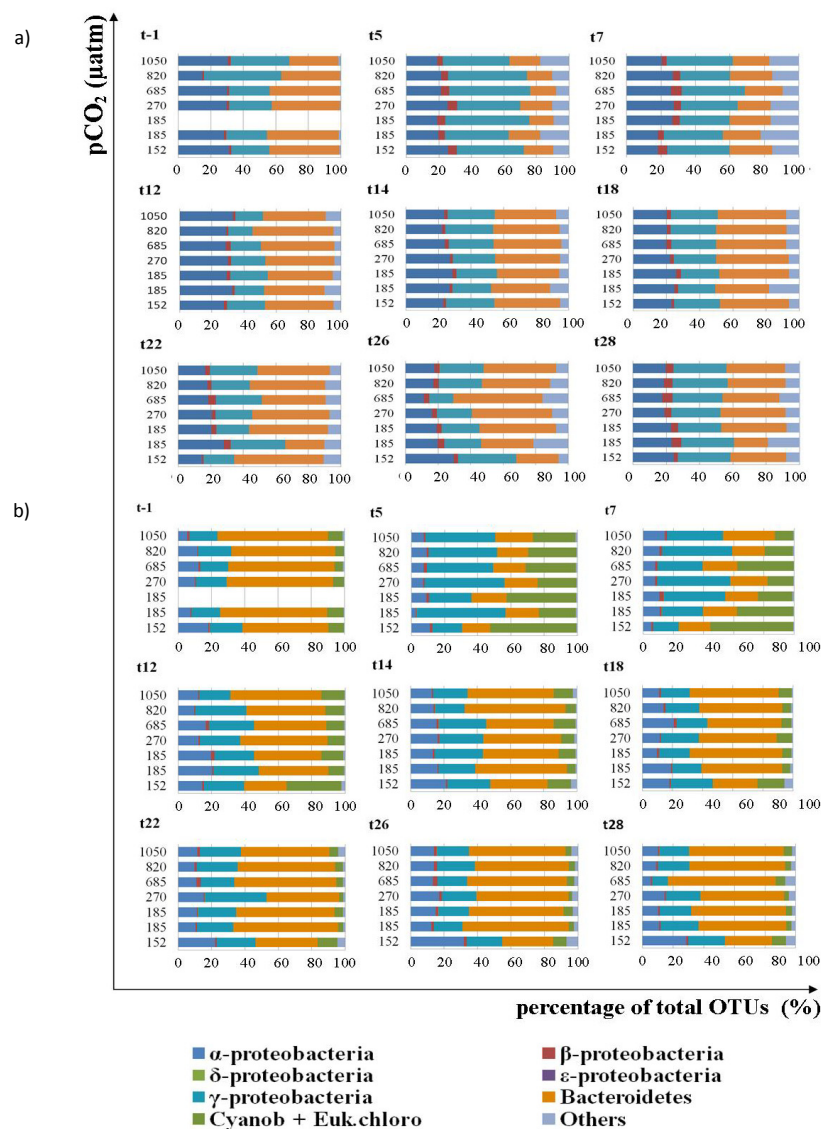

Fig. 2. Microbial community overview of the most abundant phyla in (a) the small $(0.2-3 \mu \mathrm{m})$ and (b) the large $(3-12 \mu \mathrm{m})$ size fraction during $t-1, t 5, t 7, t 12, t 14, t 18, t 22, t 26$ and $t 28$; $\mathrm{x}$-axis represents percentage of total OTUs and y-axis represents $p \mathrm{CO}_{2}$ in $\mu$ atm

nitrate $\left(\mathrm{NO}_{3}-5 \%\right)$ and origin $(4 \%)$ for the pre-nutrient period $(t-4$ to $t 12)$, and $\mathrm{Si}(27 \%)$ and origin $(12 \%)$ for the postnutrient addition period ( $t 13-t 30$; Table 2$)$. Therefore, the differences in the microbial community structure between the fjord and mesocosms were primarily due to the addition of nutrients to the mesocosms, and not to $p \mathrm{CO}_{2}$ manipulation, as the control mesocosms were not significantly different from the elevated $\mathrm{CO}_{2}$ mesocosms post-nutrient addition.

\section{3 $\mathrm{pCO}_{2}$ effect on microbial community}

Although the $p \mathrm{CO}_{2}$ treatment was not identified as a major community structuring variable, the relative abundances of 15 rare taxa (\% abundance across time and treatment was $<0.22 \%$; Table 4) were significantly correlated to $p \mathrm{CO}_{2} \mathrm{lev}$ els. From these 15 rare taxa in both small and the large size fractions, 12 showed a significant but slight increase with $p \mathrm{CO}_{2}$, having their maximum abundances in either the medium $(\sim 685$ and $\sim 820 \mu \mathrm{atm})$ or the high $(\sim 1050 \mu \mathrm{atm})$ $p \mathrm{CO}_{2}$ mesocosms. The remaining three decreased, with their highest abundances in the lowest $(\sim 185 \mu \mathrm{atm}) p \mathrm{CO}_{2}$ meso-
Table 1. Redundancy analysis showing the significant structuring variables for the whole bacterial community during the postnutrient addition period $(t 13-t 30)$. Significant values are $p<0.05$.

\begin{tabular}{lrlr}
\hline Variables & $\%$ & $p$ & $F$ \\
\hline Origin & 25 & 0.001 & 24.84 \\
Fraction & 14 & 0.001 & 17.77 \\
$\mathrm{Si}$ & 8 & 0.001 & 11.32 \\
$\mathrm{PO}_{4}$ & 2 & 0.01 & 2.83 \\
Primary production & 2 & 0.026 & 2.31 \\
Temperature & 2 & 0.042 & 2.26 \\
pH & 1 & 0.029 & 2.36 \\
\hline
\end{tabular}

Table 2. Results from RDA forward selection (with Monte Carlo permutation tests) showing only the significant $(p<0.05)$ structuring variables for the small $(0.2-3 \mu \mathrm{m})$ and the large $(3-12 \mu \mathrm{m})$ size fraction during the pre-nutrient period from $t 1$ to $t 12$ (a and $\mathrm{c}$, respectively) and post-nutrient period from $t 13$ to $t 30$ (b and d, respectively).

\begin{tabular}{|c|c|c|c|c|}
\hline \multicolumn{2}{|c|}{ Variable } & $\%$ & $p$ & $F$ \\
\hline \multicolumn{5}{|c|}{ Small size fraction } \\
\hline \multirow[t]{6}{*}{ (a) } & Dimethyl Sulphide & 16 & 0.001 & 9.79 \\
\hline & Bacterial production & 15 & 0.001 & 10.73 \\
\hline & Density & 12 & 0.001 & 9.65 \\
\hline & $\mathrm{NO}_{2}$ & 5 & 0.001 & 4.54 \\
\hline & Day & 2 & 0.024 & 2.14 \\
\hline & Origin & 3 & 0.014 & 2.53 \\
\hline \multirow[t]{11}{*}{ (b) } & Origin & 48 & 0.001 & 35.75 \\
\hline & $p \mathrm{CO}_{2}$ & 10 & 0.001 & 8.77 \\
\hline & Day & 10 & 0.001 & 11.43 \\
\hline & $\mathrm{CO}_{2}$ & 4 & 0.001 & 4 \\
\hline & Mesocosm & 2 & 0.002 & 3.27 \\
\hline & Turbidity & 3 & 0.001 & 3.91 \\
\hline & Primary production $14 \mathrm{C}$ & 1 & 0.007 & 2.3 \\
\hline & $\mathrm{NH}_{4}$ & 2 & 0.019 & 2.06 \\
\hline & Density & 1 & 0.032 & 1.99 \\
\hline & Temperature & 1 & 0.044 & 1.72 \\
\hline & $\mathrm{PO}_{4}$ & 1 & 0.033 & 1.92 \\
\hline \multicolumn{5}{|c|}{ Large size fraction } \\
\hline \multirow[t]{4}{*}{ (c) } & $\mathrm{O}_{2}$ & 7 & 0.002 & 3.81 \\
\hline & Dimethyl sulphide & 7 & 0.005 & 3.81 \\
\hline & Origin & 4 & 0.016 & 2.59 \\
\hline & $\mathrm{NO}_{3}$ & 5 & 0.014 & 2.95 \\
\hline \multirow[t]{3}{*}{ (d) } & $\mathrm{Si}$ & 27 & 0.001 & 13.36 \\
\hline & Origin & 12 & 0.001 & 7.11 \\
\hline & $\mathrm{PO}_{4}$ & 4 & 0.039 & 2.24 \\
\hline
\end{tabular}

cosm, or before manipulation started (Fig. 4, Figs. S3 and S4). The three most abundant of these 15 taxa were Methylotenera $(\beta$-proteobacteria), Colwellia $(\gamma$-proteobacteria) and Fluviicola (Bacteroidetes). Methylotenera and Colwellia abundances were at their highest in, respectively, the $\sim 686$ 
a)

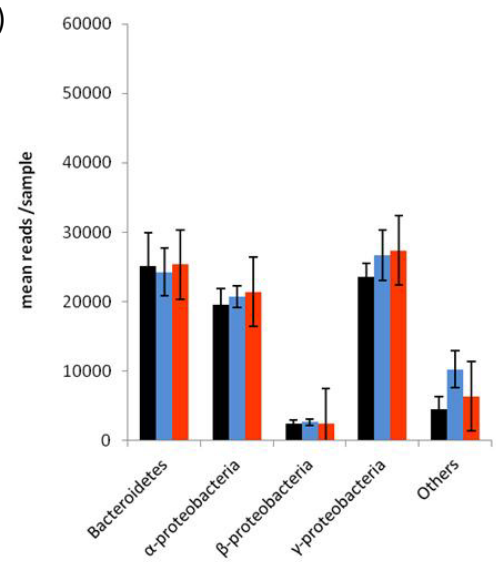

b)

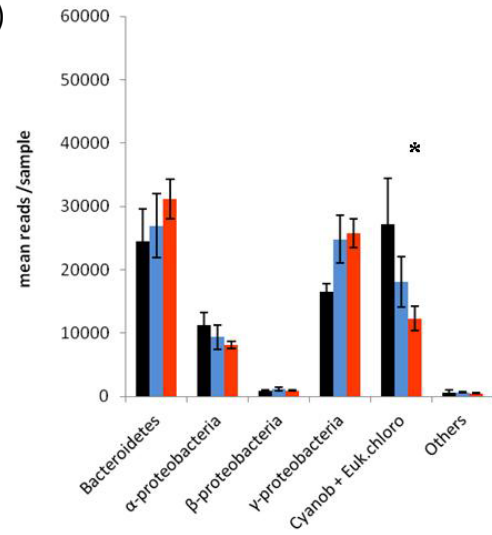

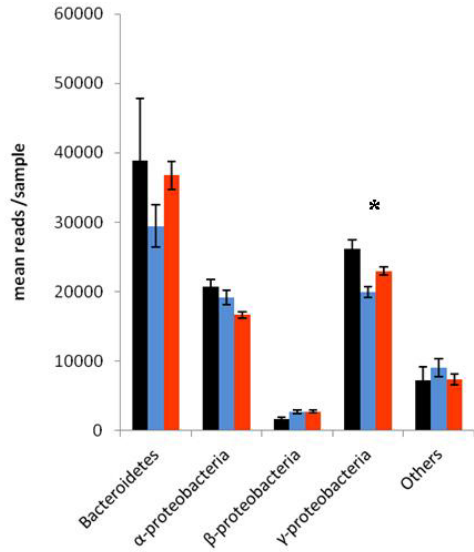

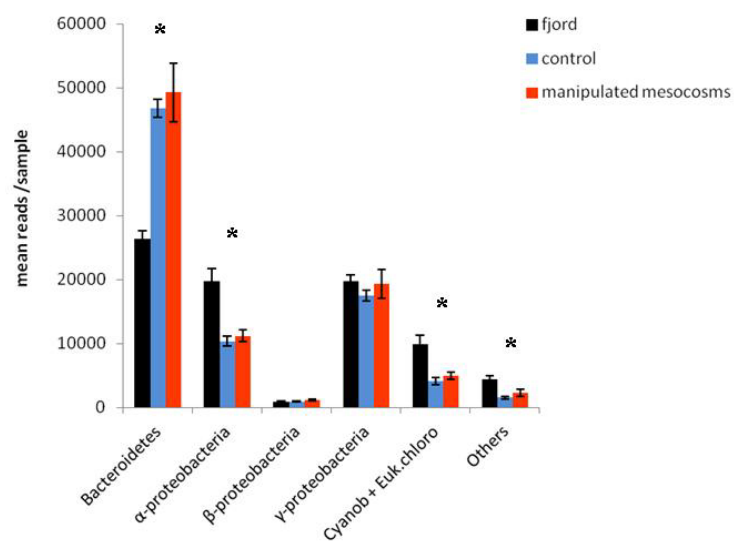

Fig. 3. Mean abundance $( \pm \mathrm{SE})$ of the main phyla of the bacterial community for the fjord $(\sim 145 \mu \mathrm{atm})$, the control $(2 \times \sim 185 \mu$ atm $)$ and the manipulated mesocosms $(\sim 270, \sim 685, \sim 820, \sim 1050 \mu \mathrm{atm})$ of the small (a) and large (b) size fraction pre- (left) and post- (right) nutrient addition. Phyla with significantly different $\mathrm{p}$ values $(<0.05)$ as a function of samples origin are marked with an *

and $\sim 824 \mu \mathrm{atm}$ mesocosms toward the end of the experiment $(t 22)$. Fluviicola was present from the beginning of the experiment, but decreased precipitously after $\mathrm{CO}_{2}$ was added and then recovered in abundance after $t 10$, reaching its highest abundance in the $1050 \mu$ atm mesocosm between $t 12$ and t22 (Fig. 4).

\section{Discussion}

\subsection{Mesocosms and structuring effects}

In this study, a large-scale mesocosm experiment was used to investigate the impacts of $\mathrm{OA}$ on the microbial community structure in a coastal, high latitude marine pelagic ecosystem. The experimental design provided the opportunity to test for the effects of four different $p \mathrm{CO}_{2}$ concentrations $(\sim 270, \sim 685, \sim 820, \sim 1050 \mu$ atm) against two negative controls $(\sim 185 \mu \mathrm{atm})$ over a six-week period. In addition, mesocosm-specific experimental artefacts were monitored by sampling the fjord microbial community throughout the course of the experiment. The microbial community structure post-nutrient-addition $(t 13)$ was significantly corre- lated with seven variables, the most influential of which was sample origin (fjord or mesocosm). The overall community structure was not significantly different between mesocosms (including control versus elevated $p \mathrm{CO}_{2}$ ) over the course of the experiment. The significant effect of the mesocosm enclosures on microbial community structure could be due to the mesocosms themselves (isolating a microbial community from the surrounding fjord community) or since the effect was not significant before nutrient addition, more likely due to the addition of nutrients into the mesocosms at $t 13$.

The sampling strategy separating the community into size fractions was the second most important variable in explaining differences in community structure. Before nutrient addition, the communities in the small size fraction were not significantly different between the fjord (ambient), control mesocosms, and the elevated $p \mathrm{CO}_{2}$ mesocosms. However, after the addition of nutrients, $\gamma$-proteobacterial abundances were significantly different between fjord and mesocosms, and probably reflected the utilization of metabolites released by decaying phytoplankton in the post-bloom system. In particular, the overall abundance of Bacteroidetes in the small and large size fractions increased in post-blooms conditions, 
Table 3. Analysis of variance (ANOVA) showing the relationship in between each treatment pre- and post-bloom condition for (a) small and (b) large size fraction bacteria of phyla with significant differences. Significant values are $p<0.05$.

\begin{tabular}{lllll}
\hline Time & Phylum & Treatment & $p$ \\
\hline (a) & Post-nutrient addition & Gamma-proteobacteria & fjord-control & 0.001 \\
& & & mesocosm-control & 0.140 \\
& & & mesocosm-fjord & 0.038 \\
& Pre-nutrient addition & "Cyanobacteria + euk.chloro" & fjord-control & 0.317 \\
& & mesocosm-control & 0.289 \\
& & mesocosm-fjord & 0.020 \\
\hline (b) & Post-nutrient addition & Bacteroidetes & fjord-control & 0.001 \\
& & mesocosm-control & 0.864 \\
& & mesocosm-fjord & 0.002 \\
& Alpha-proteobacteria & fjord-control & 0.002 \\
& & mesocosm-control & 0.787 \\
& & mesocosm-fjord & 0.006 \\
& "Cyanobacteria + euk.chloro" & fjord-control & 0.000 \\
& & mesocosm-control & 0.839 \\
& & mesocosm-fjord & 0.001 \\
& & fjord-control & 0.000 \\
& & mesocosm-control & 0.320 \\
& & mesocosm-fjord & 0.001 \\
\hline
\end{tabular}

Table 4. Bonferroni-corrected g-test of significance $(p<0.05)$ listing 15 taxa significantly correlated with $\mathrm{CO}_{2}$, for both small and large size fraction; bold highlights mark the taxa presented in Fig. 4. Greengenes OTU identifiers refer to prokMSA ids in the Greengenes database.

\begin{tabular}{|c|c|c|c|c|c|}
\hline $\begin{array}{r}\text { Greengenes } \\
\text { OTU } \\
\text { Identifier }\end{array}$ & Taxa & Abundance & $\begin{array}{l}\% \text { total } \\
\text { sequences } \\
(20863517)\end{array}$ & Response to elevated $p \mathrm{CO}_{2}$ & $p$ \\
\hline 144699 & Oceanospirillaceae (family) & 1182 & 0.006 & Increased with $p \mathrm{CO}_{2}$ & 0.000 \\
\hline 105727 & Methylotenera (genus) & 45915 & 0.220 & Highest in middle $p \mathrm{CO}_{2}$ & 0.000 \\
\hline 151803 & Flavobacteriaceae (family) & 1841 & 0.009 & Increased with $p \mathrm{CO}_{2}$ & 0.000 \\
\hline 94238 & Oxalobacteraceae (family) & 322 & 0.002 & Highest in middle $p \mathrm{CO}_{2}$ & 0.000 \\
\hline 402252 & Fluviicola (genus) & 20950 & 0.100 & Increased with $p \mathrm{CO}_{2}$ & 0.001 \\
\hline 592739 & Oleibacter (genus) & 2976 & 0.014 & Highest in middle $p \mathrm{CO}_{2} /$ Increased & 0.001 \\
\hline 262549 & HTCC-1288 (genus) & 25 & 0.001 & Mixed, highest in high-middle $p \mathrm{CO}_{2}$ & 0.001 \\
\hline 140859 & Flavobacterium Succinicans (species) & 344 & 0.0001 & Decrease with $p \mathrm{CO}_{2}$ & 0.004 \\
\hline
\end{tabular}

possibly also as a result of the dissolved organic carbon (DOC) released by a decaying algal bloom and aggregation of dying phytoplankton, respectively. The $\gamma$-proteobacteria and Bacteroidetes generally include many phytodetritusassimilating organisms (Teske et al., 2011; Abell and Bowman, 2005; Pinhassi et al., 2004) and this would explain their increase in abundance during the demise of the bloom. Despite the observation that Bacteroidetes showed bloomrelated dynamics, and contradictory to the findings of Zhang et al. (2012), no significant difference in the Bacteroidetes abundance (in either fraction) was found between the control and elevated $p \mathrm{CO}_{2}$ mesocosms, suggesting that elevated $p \mathrm{CO}_{2}$ did not impact the relative abundance of Bacteroidetes. However, their abundance in the fjord was significantly lower than in the mesocosms, suggesting that the nutrient addition or influence of the mesocosm enclosure did have an impact. 
a)

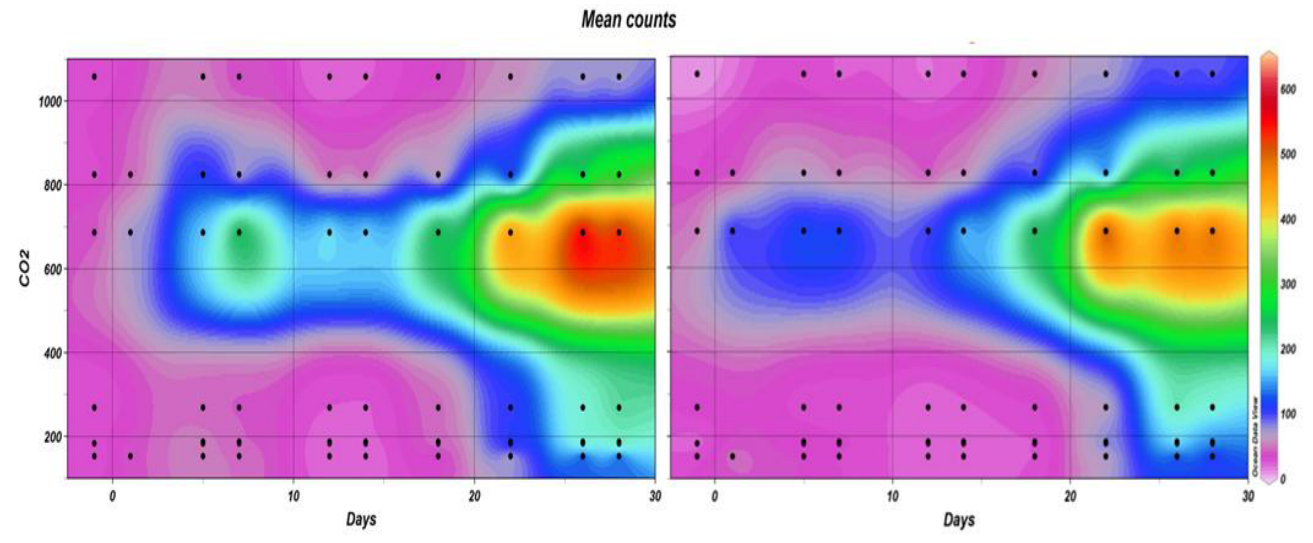

b)

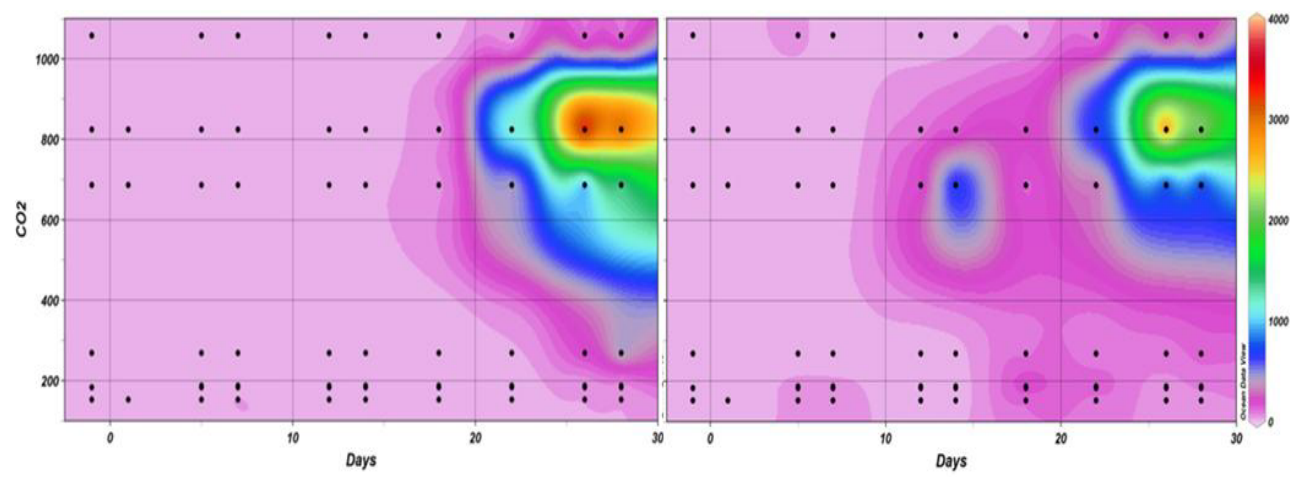

c)
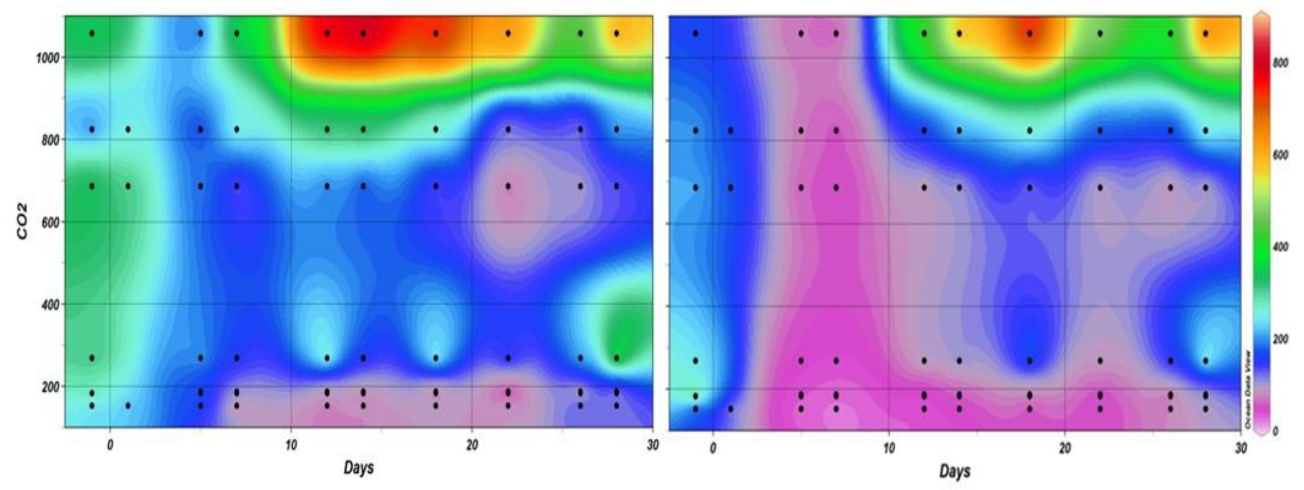

Fig. 4. Contour plots presenting the continuous interpolated mean abundance count of the three most abundant taxa that are significantly affected by $p \mathrm{CO}_{2}$ levels (a) Methylotenera (b) Colwellia and (c) Fluviicola plotted against $p \mathrm{CO}_{2}$ ( $\mu$ atm, $y$-axis) and time (days, $x$-axis). Left and right panel represent, respectively, the small $(0.2-3 \mu \mathrm{m})$ and large $(3-12 \mu \mathrm{m})$ size fraction.

The large size fraction in the mesocosms also showed differences in the relative abundance of dominant phyla following nutrient addition ( $t 13)$. It has previously been established that particle-associated assemblages were predominantly connected to phytoplankton development (Riemann et al., 2000; Allgaier et al., 2008). Furthermore, differences in the "Cyanobacteria and eukaryotic chloroplasts" group were measurable before nutrient addition. However these differences appear to be related to the natural phytoplankton bloom (which occurred in the fjord and mesocosms) that reached its maximum on $t 7$. The "post-nutrient addition" differences were significant between the fjord and mesocosms for almost every abundant phyla throughout the different phytoplankton phases; suggesting that nutrient addition influenced autotrophic and heterotrophic microbial community structure. However, no significant differences were found between the control and the elevated mesocosms, which suggests that high $p \mathrm{CO}_{2}$ level was not an important communitystructuring variable for the large size fraction in this experiment. Silica was the third most important structuring variable 
and is potentially related to diatom abundance (de Kluijver et al., 2010). The recycling of Si from decaying diatoms, after a phytoplankton bloom, is carried out by a diverse fast growing bacteria related to cytophagales (from Flavobacteria; Riemann et al., 2000). Indeed, an increase in the abundance of Bacteroidetes, which contains the Flavobacteria, was observed in the post-nutrient addition phase.

However, no single environmental variable could account for the microbial community composition of the large and small size fractions for all of the phases of the mesocosm experiment (Fig. 1). Rather a shift was observed between pre- and post-nutrient addition with DMS concentration as the most influential variable for the small size fraction under pre-nutrient addition, while origin (Fjord vs. mesocosm) was most influential under post-nutrient addition conditions. Oxygen and $\mathrm{Si}$ were the most significant structuring variables for the large size fraction for the pre- and post-nutrient addition, respectively. Variables associated with phytoplankton bloom dynamics were most important for structuring the community, especially when looking at the taxonomic shifts between fjord, control mesocosms and elevated $p \mathrm{CO}_{2}$ mesocosms. The differences were greater after $t 13$ because of the two subsequent phytoplankton blooms that were triggered by the nutrient addition. The differences were most evident in the large size fraction, probably due to the association of the bacterial community with phytoplankton aggregates. Therefore, it is possible to state that nutrients, and the phytoplankton blooms, were the main drivers of microbial community structure in this experiment, which is in agreement with previous (Allgaier et al., 2008; de Kluijver et al., 2010) and present studies (Sperling et al., 2013).

\subsection{Elevated $\mathrm{pCO}_{2}$ effect}

The effect of elevated $p \mathrm{CO}_{2}$ on microbial community structure has also been investigated in previous (Newbold et al., 2012) or present mesocosms (Zhang et al., 2012), where no evidence of a major $p \mathrm{CO}_{2}$ effect on the general bacterial community was found. However, other work suggests that only the community structure of the small size fraction bacteria is significantly affected by elevated $p \mathrm{CO}_{2}$ (Allgaier et al., 2008). The extensive database of $16 \mathrm{~S}$ rRNA sequence obtained in this study provided the high resolution necessary to study subtle but significant changes in community structure hinted at in prior studies. In agreement with Allgaier et al. (2008), the effect of elevated $p \mathrm{CO}_{2}$ in this experiment was slight and only impacted the small size fraction bacteria after nutrient addition, which corresponded to post-nutrient addition and post-bloom conditions (after $t 13$ ) in this study. This increased post-bloom $\mathrm{CO}_{2}$ effect was previously observed in other mesocosms experiments (Arnosti et al., 2011; de Kluijver et al., 2010), confirming a possible increased $\mathrm{CO}_{2}$ effect under nutrient $(\mathrm{N}, \mathrm{P}, \mathrm{Si})$ limitation.

While $\mathrm{pH}$ was shown to be a weak driver of microbial community structure in our experiment, the direct impact of $p \mathrm{CO}_{2}$ was found to be non-significant, except for 15 rare taxa, which did show a response to elevated $\mathrm{CO}_{2}$. Therefore, the level of taxonomic resolution afforded by this study suggests that, in this ecosystem, rare organisms may be disproportionately affected by acidification. The most abundant of these 15 rare taxa was Methylotenera (genus) and had its highest mean abundance in the medium $p \mathrm{CO}_{2}$ mesocosms $(\sim 685 \mu \mathrm{atm})$. Species from this genus are generally aerobic, ubiquitous bacteria found in a wide range of $\mathrm{O}_{2}$, salinity, temperature and $\mathrm{pH}$. Methylotenera can colonize multiple $\mathrm{pH}$ range (5 to 8.5 ) but grows optimally at $\mathrm{pH} 7.5$ (Kalyuzhnaya et al., 2006; Bosch et al., 2009), suggesting that $\mathrm{pH}$ may strongly influence for distribution of this taxa. Indeed, the $\mathrm{pH}$ close to this value from $t 5$ until the end of the experiment in the mesocosms with a $p \mathrm{CO}_{2}$ over $\sim 685 \mu$ atm. The highest abundance was found from $t 22$ until $t 28$ where the $\mathrm{pH}$ was 7.9 and 7.94. A lower $\mathrm{pH}$ was found (pHT 7.577.80 ) in the $\sim 1050 \mu \mathrm{atm}$ mesocosm but this was not accompanied by an increase in Methylonera abundance, potentially because the $p \mathrm{CO}_{2}$ concentration itself was toxic to this species at this stage or this could represent mesocosm variability, suggesting a need for improved replication. Functionally, the species included in this genus have been described as bacteria that require organic compounds containing no carbon-carbon bonds $\left(\mathrm{C}_{1}\right.$ compounds) like methylamine and/or methanol as energy sources (Lidstrom, 2006; Kalyuzhnaya et al., 2006, 2010). These organic compounds play an important role in the global carbon cycle because they are greenhouse gases whose emissions are on a scale similar to methane (Chistoserdova et al., 2009). Further investigation of the behaviour of these $\mathrm{C}_{1}$-compounddegraders in response to elevated $\mathrm{CO}_{2}$ are, therefore, important for understanding biotic influences on climate dynamics. The second most abundant group of the $15 p \mathrm{CO}_{2}$-correlated rare taxa was Colwellia, which is a versatile group with broad temperature range tolerance. For example, the psychrophilic Arctic marine strain Colwellia psychrerythraea grows at a range of temperature from -1 to $10^{\circ} \mathrm{C}$ (optimal growth $8^{\circ} \mathrm{C}$ ), Colwellia chuckchiensis at a range from 0 to $30^{\circ} \mathrm{C}$ and Colwellia asteriadis spp. at a range from 4 to $25^{\circ} \mathrm{C}$. These organisms are also capable of colonising a wide range of $\mathrm{pH}$ from 4 to 10 (Yu et al., 2011; Choi et al., 2010; Methé et al., 2005). C. psychrerythrea is considered a model organism for psychrophiles and shows multiple molecular adaptations to the cold, like enzymes for cryoprotection, for dissolving high-molecular-weight organic compounds (ex. carbon), for stability in extreme environments (extracellular polymeric substances) and for cold-active processes (Methé et al., 2005; Huston et al., 2004). These features make Colwellia spp. key participants in carbon and nutrient cycling in the cold marine environments. Since some methanogenic enzymes were previously found in Colwellia spp. (Methé, et al., 2005) one can speculate that these compounds were found in greater abundance toward the end of the experiment. This would also support the presence of the Methylotenera, which increased 
in abundance towards the end of the experiment. Finally the genus Fluviicola, the third most abundant OTU correlated with $p \mathrm{CO}_{2}$, was dominant in the elevated $\mathrm{CO}_{2}$ mesocosms $(\sim 1058 \mu \mathrm{atm})$. Interestingly, Fluviicola was present at the beginning of the experiment but decreased shortly after $\mathrm{CO}_{2}$ treatment started. The abundance increased under elevated $p \mathrm{CO}_{2}$, but stayed low in medium $p \mathrm{CO}_{2}$ mesocosms and absent in the controls, for both size fractions. Little is known about this genus, making speculations about its ecological role difficult.

\section{Conclusions}

In summary, multiple parameters were found to significantly influence the structure of the bacterial community in Svalbard mesocosms. The most influential factors were the origin of the sample (fjord or mesocosms) and nutrient addition. Furthermore, the relative importance of sampling strategy (small versus large size fraction), $\mathrm{Si}, \mathrm{PO}_{4}$, primary production, temperature, and $\mathrm{pH}$ in structuring the community depended greatly on the time at which the community was sampled in relation to the phytoplankton blooms. The direct impact of $p \mathrm{CO}_{2}$ was found to be significant for only 15 rare taxa and should be further investigated as analysis of low abundance community members is known to be problematic in 16S surveys (Bokulich et al., 2013). If confirmed, this limited $p \mathrm{CO}_{2}$ effect could have evolutionary consequences creating a shift in the taxa dominance and/or diversity, profoundly affecting the structure of entire community in a high $\mathrm{CO}_{2}$ world. However, it should be noted that the $p \mathrm{CO}_{2}$ conditions in which these organisms dominated were super-elevated compared to predicted outcomes for the surface ocean under current climate change scenarios. Furthermore, the evolutionary response of the unicellular eukaryote Emiliania huxleyi to elevated $\mathrm{CO}_{2}$ was studied by Lohbeck et al. (2012) and showed that only 500 asexualgenerations were necessary to permit evolution either via adaptive changes from diverse genotype selection or via new mutations. It would be interesting to investigate how the bacterial communities from the present mesocosms experiment would evolve faced to extended elevated $\mathrm{CO}_{2}$ exposure, allowing a longer population growth.

Future work should focus on exploring the functional responses of the community (metagenomics/metatranscriptomics) to evaluate how elevated $p \mathrm{CO}_{2}$ or $\mathrm{OA}$ influence these processes over a longer time period.

\section{Supplementary material related to this article is

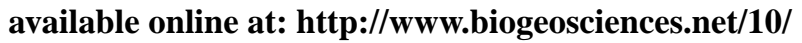 555/2013/bg-10-555-2013-supplement.pdf.}

Acknowledgements. This work is a contribution to the "European Project on Ocean Acidification" (EPOCA), which received funding from the European Community's Seventh Framework Programme (FP7/2007-2013) under grant agreement no. 211384. We gratefully acknowledge the logistical support of Greenpeace International for its assistance with the transport of the mesocosm facility from Kiel to Ny-Ålesund and back to Kiel. We also thank the captains and crews of M/V ESPERANZA of Greenpeace and R/V Viking Explorer of the University Centre in Svalbard (UNIS) for assistance during mesocosm transport and during deployment and recovery in Kongsfjorden. We thank the staff of the French-German Arctic Research Base at Ny-Ålesund, in particular Marcus Schumacher, for on-site logistical support. We would like to thank Mesoaqua for supporting J. I. N. in the field trip time to Svalbard on grant METAEPOCA. We also want to thank Tina Baustian for her help during the RNA/DNA extraction. Finally, the funding for S. M. G. was provided by NIH Training Grant 5T-32EB-009412.

The service charges for this open access publication have been covered by a Research Centre of the Helmholtz Association.

Edited by: T. F. Thingstad

\section{References}

Abell, G. C. J. and Bowman, J. P.: Ecological and biogeographic relationships of class Flavobacteria in the Southern Ocean, FEMS Microbiol. Ecol., 51, 265-277, 2005.

Agogué, H., Lamy, D., Neal, P. R., Sogin, M. L., and Herndl, G. J.: Water mass-specificity of bacterial communities in the North Atlantic revealed by massively parallel sequencing, Mol. Ecol., 20, 258-274, 2011.

Allgaier, M., Riebesell, U., Vogt, M., Thyrhaug, R., and Grossart, H.-P.: Coupling of heterotrophic bacteria to phytoplankton bloom development at different $p \mathrm{CO}_{2}$ levels: a mesocosm study, Biogeosciences, 5, 1007-1022, doi:10.5194/bg-5-10072008, 2008.

Arnosti, C., Grossart, H. P., Mühling, M., Joint, I., and Passow, U.: Dynamics of extracellular enzyme activities in seawater under changed atmospheric $p \mathrm{CO}_{2}$ : a mesocosm investigation, Aquat. Microb. Ecol., 64, 285-298, 2011.

Bellerby, R. G. J., Silyakova, A., Nondal, G., Slagstad, D., Czerny, J., De Lange, T., and Ludwig, A.: Marine carbonate system evolution during the EPOCA Arctic pelagic ecosystem experiment in the context of simulated future Arctic ocean acidification, Biogeosciences, in review, 2013.

Bokulich, N. A., Subramanian, S., Faith, J. J., Gevers, D., Gordon, J. I., Knight, R., Mills, D. A., and Caporaso, J. G.: Quality-filtering vastly improves diversity estimates from Illumina amplicon sequencing, Nat. Methods, 10, 57-59, doi:10.1038/nmeth.2276, 2013.

Bosch, G., Wang, T., Latypova, E., Kalyuzhnaya, M. G., Hackett, M., and Chistoserdova, L.: Insights into the physiology of Methylotenera mobilis as revealed by metagenome-based shotgun proteomic analysis, Microbiology, 155, 1103-1110, 2009.

Caporaso, J. G., Kuczynski, J., Stombaugh, J., Bittinger, K., Bushman, F. D., Costello, E. K., Fierer, N., Peña, A. G., Goodrich, J. K., Gordon, J. I., Huttley, G. A., Kelley, S. T., Knights, 
D., Koenig, J. E., Ley, R. E., Lozupone, C. A., McDonald, D., Muegge, B. D, Pirrung, M., Reeder, J., Sevinsky, J. R., Turnbaugh, P. J., Walters, W. A., Widmann, J., Yatsunenko, T., Zaneveld, J., and Knight, R.: QIIME allows analysis of highthroughput community sequencing data, Nat. Methods, 7, 335$336,2010$.

Caporaso, J. G., Lauber, C. L., Walters, W. A., Berg-Lyons, D., Huntley, J., Fierer, N., Owens, S. M., Betley, J., Fraser, L., Bauer, M., Gormley, N., Gilbert, J. A., Smith, G., and Knight, R.: Ultra-high-throughput microbial community analysis on the Illumina HiSeq and MiSeq platforms, ISME J., 6, 1621-1624, doi:10.1038/ismej.2012.8, 2012.

Chistoserdova, L., Kalyuzhnaya, M. G., and Lapidus, A.: The Expanding World of Methylotrophic Metabolism, Annu. Rev. Microbiol., 63, 477-499, doi:10.1146/annurev.micro.091208.073600, 2009.

Choi, E. J., Kwon, H. C., Koh, H. Y., Kim, Y. S., and Yang, H. O.: Colwellia asteriadis sp. nov., a marine bacterium isolated from the starfish Asterias amurensis, Int. J. Syst. Evol. Micr., 60, 1952-1957, doi:10.1099/ijs.0.016055-0, 2010.

Czerny, J., Schulz, K. G., Boxhammer, T., Bellerby, R. G. J., Büdenbender, J., Engel, A., Krug, S. A., Ludwig, A., Nachtigall, K., Nondal, G., Niehoff, B., Siljakova, A., and Riebesell, U.: Element budgets in an Arctic mesocosm $\mathrm{CO}_{2}$ perturbation study, Biogeosciences, in review, 2013a.

Czerny, J., Schulz, K. G., Ludwig, A., and Riebesell, U.: A simple method for gas exchange measurements in mesocosms and its application for carbon budgeting, Biogeosciences, accepted, 2013b.

de Kluijver, A., Soetaert, K., Schulz, K. G., Riebesell, U., Bellerby, R. G. J., and Middelburg, J. J.: Phytoplankton-bacteria coupling under elevated $\mathrm{CO}_{2}$ levels: a stable isotope labelling study, Biogeosciences, 7, 3783-3797, doi:10.5194/bg-7-3783-2010, 2010.

Delille, B., Harlay, J., Zondervan, I., Jacquet, S., Chou, L., Wollast, R., Bellerby, R. G. J., Frankignoulle, M., Borges, A. V., Riebesell, U., and Gattuso, J. P.: Response of primary production and calcification to changes of $p \mathrm{CO}_{2}$ during experimental blooms of the coccolithophorid Emiliania huxleyi, Global Biogeochem. Cy., 19, GB2023, doi:10.1029/2004GB002318, 2005.

Falkowski, P. G., Fenchel, T., and Delong, E. F.: The microbial engines that drive Earth's biogeochemical cycles, Science, 320,1034-1039, 2008.

Fu, F.-X., Mulholland, M. R., Garcia, N. S., Beck, A., Bernhardt, P. W., Warner, M. E., Sañudo-Wilhelmy, S. A., and Hutchins, D. A.: Interactions between changing $p \mathrm{CO}_{2}, \mathrm{~N}_{2}$ fixation, and $\mathrm{Fe}$ limitation in the marine unicellular cyanobacterium Crocosphaera, Limnol. Oceanogr., 53, 2472-2484, 2008.

Gilbert, J. A., Field, D., Swift, P., Newbold, L., Oliver A., Smyth, T., Somerfield, P. J., Huse, S., and Joint, I.: The seasonal structure of microbial communities in the Western English Channel, Environ. Microbiol., 11, 3132-3139, 2009.

Grossart, H.-P., Allgaier, M., Passow, U., and Riebesell, U.: Testing the effect of $\mathrm{CO}_{2}$ concentration on dynamics of marine heterotrophic bacterioplankton, Limnol. Oceanogr., 51, 1-11, 2006.

Hubert, J. A., Welch, D. M., Morrison, H. G., Huse, S. M., Neal, P. R., Butterfield, D. A., and Sogin, M. L.: Microbial population structures in the deep marine biosphere, Science, 318, 97-100, doi:10.1126/science.1146689, 2007.
Huse, S. M., Dethlefsen, L., Huber, J. A., Welch, D. M., Relman, D. A., and Sogin, M. L.: Exploring Microbial Diversity and Taxonomy Using SSU rRNA Hypervariable Tag Sequencing, PLoS Genet, 4, e1000255, doi:10.1371/journal.pgen.1000255, 2008.

Huston, A. L., Methé, B., and Deming J. W.: Purification, Characterization, and Sequencing of an Extracellular Cold-Active Aminopeptidase Produced by Marine Psychrophile Colwellia psychrerythraea Strain 34H, Appl. Environ. Microbiol., 70, 3321-3328, doi:10.1128/AEM.70.6.3321-3328.2004, 2004.

Hutchins, D. A., Fu, F.-X., Zhang, Y., Warner, M. E., Feng, Y., Portune, K., Bernhardt, P. W., and Mulholland, M. R.: $\mathrm{CO}_{2}$ control of Trichodesmium $\mathrm{N}_{2}$ fixation, photosynthesis, growth rates, and elemental ratios: Implications for past, present, and future ocean biogeochemistry, Limnol. Oceanogr., 52, 1293-1304, 2007.

Kalyuzhnaya, M. G., Bowerman, S., Lara, J. C., Lidstrom, M. E., and Chistoserdova, L.: Methylotenera mobilis gen. nov., sp. nov., an obligately methylamine-utilizing bacterium within the family Methylophilaceae, Int. J. Syst. Evol. Microbiol., 56, 2819-2823, 2006.

Kalyuzhnaya, M. G., Beck, D. A. C., Suciu, D., Pozhitkov, A., Lidstrom, M. E. and Chistoserdova, L.: Functioning in situ: gene expression in Methylotenera mobilis in its native environment as assessed through transcriptomics, ISME J., 4, 388-398, 2010.

Legendre, P. and Gallagher, E. D.: Ecologically meaningful transformations for ordination of species data, Oecologia, 129, 271280, 2001.

Lidstrom, M. E.: Aerobic methylotrophic prokaryotes, in: The Prokaryotes, edited by: Balows, A., Truper, H. G., Dworkin, M., Harder, W., and Schleifer, K.-H., Springer, New York, 618-634, 2006.

Lohbeck, K. T., Riebesell, U., and Reusch, T. B. H.: Adaptive evolution of a key phytoplankton species to ocean acidification, Nat. Geosci., 5, 346-351, doi:10.1038/NGEO1441, 2012.

Lozupone, C. and Knight, R.: UniFrac: a new phylogenetic method for comparing microbial communities, Appl. Environ. Microbiol., 71, 8228-8235, 2005.

Margulies, M., Egholm, M., Altman, W. E., Attiya, S., Bader, J. S., Bemben, L. A., Berka, J., Braverman, M. S., Chen, Y.-C., Chen, Z., Dewell, S. B., Du, L., Fierro, J. M., Gomes, X. V., Godwin, B. C., He, W., Helgesen, S., He Ho, C., Irzyk, G. P., Jando, S. C., Alenquer, M. L. I., Jarvie, T. P., Jirage, K. B., Kim, J.-B., Knight, J. R., Lanza, J. R., Leamon, J. H., Lefkowitz, S. M., Lei, M., Li, J., Lohman, K. L., Lu, H., Makhijani, V. B., McDade, K. E., McKenna, M. P., Myers, E. W., Nickerson, E., Nobile, J. R., Plant, R., Puc, B. P., Ronan, M. T., Roth, G. T., Sarkis, G. J., Simons, J. F., Simpson, J. W., Srinivasan, M., Tartaro, K. R., Tomasz, A., Vogt, K. A., Volkmer, G. A., Wang, S. H., Wang, Y., Weiner, M. P., Yu, P., Begley, R. F., and Rothberg, J. M.: Genome sequencing in microfabricated high-density picolitre reactors, Nature, 437, 376-380, 2005.

McDonald, D., Price, M. N., Goodrich, J., Nawrocki, E. P., DeSantis, T. Z., Probst, A., Andersen, G. L., Knight, R., and Hugenholtz, P.: An improved Greengenes taxonomy with explicit ranks for ecological and evolutionary analyses of bacteria and archaea, ISME J., 6, 610-618, 2012.

Methé, B. A., Nelson, K. E., Deming, J. W., Momen, B., Melamud, E., Zhang, X., Moult, J., Madupu, R., Nelson, W. C., Dodson, R. J., Brinkac, L. M., Daugherty, S. C., Durkin, A. S., Deboy, R. T., Kolonay, J. F., Sullivan, S. A., Zhou, L., Davidsen, T. M., Wu, M., 
Huston, A. L., Lewis, M., Weaver, B., Weidman, J. F., Khouri, H., Utterback, T. R., Feldblyum, T. V., and Fraser, C. M.: The psychrophilic lifestyle as revealed by the genome sequence of Colwellia psychrerythraea $34 \mathrm{H}$ through genomic and proteomic analyses, P. Natl. Acad. Sci., 102, 10913-10918, 2005.

Newbold, L. K., Oliver, A. E., Booth, T., Tiwari, B., DeSantis, T., Maguire, M., Andersen, G., van der Gast, C. J., and Whiteley, A. S.: The response of picoplankton to ocean acidification, Environ. Microbiol., 14, 2293-2307, doi:10.1111/j.14622920.2012.02762.x, 2012.

Pinhassi, J., Sala, M. M., Havskum, H., Peters, F., Guadayol, O., Malits, A., and Marrase, C.: Changes in bacterioplankton composition under different phytoplankton regimens, Appl. Environ. Microb., 70, 6753-6766, 2004.

Ramette, A.: Multivariate analyses in microbial ecology, FEMS Microbiol. Ecol., 62, 142-160, 2007.

Riebesell, U., Bellerby, R. G. J., Grossart, H.-P., and Thingstad, F.: Mesocosm $\mathrm{CO}_{2}$ perturbation studies: from organism to community level, Biogeosciences, 5, 1157-1164, doi:10.5194/bg-51157-2008, 2008.

Riebesell, U., Czerny, J., von Bröckel, K., Boxhammer, T., Büdenbender, J., Deckelnick, M., Fisher, M., Hoffmann, D., Krug, S.A., Lenz, U., Ludwig, A., and Schulz, K. G.: Technical Note: A mobile sea-going mesocosm system: New opportunities for ocean change research, Biogeosciences, in review, 2013.

Riemann, L., Steward, G. F., and Azam, F.: Dynamics of Bacterial Community Composition and Activity during a Mesocosm Diatom Bloom, Appl. Environ. Microb., 66, 578-587, 2000.

Schulz, K. G., Bellerby, R. G. J., Brussaard, C. P. D., Büdenbender, J., Czerny, J., Fischer, M., Koch-Klavsen, S., Krug, S., Lischka, S., Ludwig, A. M. M., Nondal, G., Silyakova, A., Stuhr, A., and Riebesell, U.: Temporal biomass dynamics of an Arctic plankton bloom in response to increasing levels of atmospheric carbon dioxide, Biogeosciences, 10, 161-180, doi:10.5194/bg-10-1612013, 2013.

Sogin, M .L., Morrison, H. G., Huber, J. A., Welch, D. M., Huse, S. M., Neal, P. R., Arrieta, J. M., and Herndl, G. J.: Microbial diversity in the deep sea and the underexplored "rare biosphere", P. Natl. Acad. Sci., 103, 12115-12120, doi:10.1073/pnas.0605127103, 2006.
Sperling, M., Piontek, J., Gerdts, G., Wichels, A., Schunck, H., Roy, A.-S., La Roche, J., Gilbert, J., Nissimov, J. I., Bittner, L., Romac, S., Riebesell, U., and Engel, A.: Effect of elevated $\mathrm{CO}_{2}$ on the dynamics of particle-attached and free-living bacterioplankton communities in an Arctic fjord, Biogeosciences, 10, 181191, doi:10.5194/bg-10-181-2013, 2013.

Tanaka, T., Thingstad, T. F., Lovdal, T., Grossart, H.-P., Larsen, A., Allgaier, M., Meyeröfer, M., Schulz, K. G., Wohlers, J., Zöllner, E., and Riebesell, U.: Availability of phosphate for phytoplankton and bacteria and of glucose for bacteria at different $p \mathrm{CO}_{2}$ levels in a mesocosm study, Biogeosciences, 5, 669-678, doi:10.5194/bg-5-669-2008, 2008.

ter Braak, C. J. F. and Šmilauer, P.: CANOCO Reference Manual and Cano-Draw for Windows User's Guide, in: Software for Canonical Community Ordination Version 4.5 Microcomputer Power, Centrum voor biometrie, Plant research international Wageningen UR, Ithaca, NY, USA, p. 500, 2002.

Teske, A., Durbin, A., Ziervogel, K., Cox, C., and Arnosti, C.: Microbial community composition and function in permanently cold seawater and sediment from an Arctic fjord of Svalbard, Appl. Environ. Microbiol., 77, 2008-2018, doi:10.1128/AEM.01507-10, 2011.

Wang Q., Garrity, G. M., Tiedje, J. M. and Cole, J. R.: Naive Bayesian classifier for rapid assignment of rRNA sequences into the new bacterial taxonomy, Appl. Environ. Microbiol., 2007, 5261-5267, 2007.

Worden, A. Z., and Not, F.: Ecology and diversity of picoeukaryotes, in: Microbial Ecology of the Oceans, 2nd Edn., edited by: Kirchman, D. L., Hoboken, NJ, USA, John Wiley \& Sons, 159205, 2008.

Yu, Y., Li, H.-R., and Zeng, Y.-X.: Colwellia chukchiensis sp. nov., a psychrotolerant bacterium isolated from the Arctic Ocean, Int J. Syst. Evol. Micr., 61, 850-853, 2011.

Zhang, R., Xia, X., Lau, S. C. K., Motegi, C., Weinbauer, M. G., and Jiao, N.: Response of bacterioplankton community structure to an artificial gradient of $p \mathrm{CO}_{2}$ in the Arctic Ocean, Biogeosciences Discuss., 9, 10645-10668, doi:10.5194/bgd-9-106452012, 2012. 